\title{
Discurso antiprotestante en Miguel Ángel Builes
}

Fabio Hernán Carballo'

Universidad de Antioquia

Artículo de Reflexión derivado de Investigación

Recibido: Enero 03 de 2017 Aprobado: Mayo 19 de 2017

\section{Resumen}

La vida de Miguel Ángel Builes Gómez, Obispo de la Diócesis de Santa Rosa de Osos entre 1924 y 1967, estuvo marcada por la polémica. Desde muy joven el futuro prelado mostró su talante misionero y combativo en los trabajos a los que fue designado. Entre sus enemigos terrenales estaban los protestantes, aquellos que desde principios del siglo XX se venían instalando en lo que sería su Diócesis. Este artículo pretende analizar el discurso antiprotestante de monseñor Builes, teniendo en cuenta la pastoral de 1948, "El Protestantismo" y su alocución en junio del mismo año denominada "El Juramento Católico". Busca integrar las palabras de Builes a su vida y teología haciendo un intento por conectar su antiprotestantismo con la interpretación que tenía de los eventos nacionales e internacionales de la época.

Palabras clave: Antioquia, discurso, Miguel Ángel Builes, liberalismo, protestantismo.

\section{Antiprotestant speech in Miguel Ángel Builes}

\section{Abstract}

The life of Miguel Ángel Builes Gómez, Bishop of the Diocese of Santa Rosa de Osos between 1924 and 1967, was marked by mishap. From an early age, the future prelate demonstrated his talent as a missionary in the tasks assigned to him. In his earthly enemies were the Protestants, who from the

I Historiador Universidad de Antioquia. Profesor universitario en las asignaturas de Historia Socio-económica de Colombia, siglos XIX y XX, Historia de América Latina siglo XX, Catolicismo y Protestantismo en Colombia. Magister en Historia de la Universidad de Antioquia. Correo electrónico: carballol602@gmail.com 
beginning of $X X$ century started to settle in his Diocese. The intentions of this article is to analyze the antiprotestant speech of Mgr Builes, taking into account pastoral of 1948, "El Protestantismo" and his June address of the same year titled "El Juramento Católico". It seeks to integrate the words of Builes to his life and theology attempting to connect his anti-protestantism with an interpretation of national and international events of the time.

Key Words: Antioquia, speech, Miguel Ángel Builes, liberalism, protestantism.

\section{Discurso antiprotestante em Miguel Ángel Builes}

\section{Resumo}

A vida de Miguel Builes Gómez, bispo da Diocese de Santa Rosa de Osos entre os anos de 1924 e 1967, foi muito polêmica. Desde muito novo foi evidente o talante missioneiro e combativo do religioso, que virou inimigo dos protestantes que desde inicios do século $X X$ vinham se instalando na Diocese dele. Este artigo visa analisar o discurso antiprotestante do Monsenhor Builes, considerando a pastoral de 1948 chamada $\bigcirc$ Protestantismo, mesmo como seu depoimento em junho do mesmo ano denominada $\bigcirc$ juramento Católico. A análise associa o discurso com a experiência de vida e a teologia de Builes, conectando seu sentimento antiprotestante com a interpretação que ele fazia de eventos nacionais e internacionais acontecidos nessa época.

Palavras chave: Antioquia, discurso, Miguel Ángel Builes, liberalismo, protestantismo.

Entretanto se trabó una batalla grande en el cielo:

Miguel y sus ángeles peleaban contra el dragón $[\ldots]^{2}$.

Miguel Ángel Builes Gómez nació en la vereda de Las Juntas en Donmatías, Antioquia, el 9 de septiembre de 1888. El futuro y polémico obispo de Santa Rosa de Osos provenía de un hogar devoto y campesino. Hijo de Agustín Builes y Ana María Gómez, estudió la primaria en Donmatías, la secundaria y los estudios sacerdotales en el Seminario Menor de San Pedro y el Seminario Mayor de Santafé de Antioquia. Fue ordenado como sacerdote el 29 de noviembre de 1914; el 8 de diciembre, día de la Inmaculada Concepción cantó su primera misa en Donmatías. Cooperó como vicario en la parroquia de Valdivia y el 28 de noviembre de 1916, a los 28 años, ejerció su trabajo ministerial como párroco interino del actual municipio de Toledo en el norte de Antioquia33.

2 La Sagrada Biblia. Por Don Félix Torres Amat. Madrid: Imprenta de León Amarita, I824. Apocalipsis I2:6.

3 Mírense los siguientes trabajos: SANÍN ECHEVERRI, Jaime. El Obispo Builes. Medellín: Editorial Géminis, I988; ZAPATA RESTREPO, Miguel. La mitra azul. Miguel Ángel Builes: El hombre, el obispo, el caudillo. Medellín: Editora Beta, I973; OLANO GARCíA, María Dolly. Monseñor Builes, el hombre, el apóstol, el místico. Cali: Cuadernos de vida cristiana, 1979. 
En enero de 1919, cuando Builes rondaba los 30 años, fue designado como párroco interino de la parroquia de Remedios, pueblo en el nordeste del departamento con características geográficas y sociales diferentes a Toledo, a Donmatías y a Santa Rosa, lugares donde había pasado la mayoría de su vida y donde nació su vocación. A diferencia de los tres pueblos montañosos y agrícolas atrás mencionados, la principal actividad económica de Remedios era la minería.

\section{Encuentro con la herejía}

Entre junio de 1920 y junio de 1921, el sacerdote fue encomendado a apoyar en el ministerio al presbítero Ignacio Yepes en Valdivia. De este interregno en Valdivia, dice Miguel Zapara Restrepo, en el libro biográfico sobre Builes La Mitra Azul, que el padre Yepes "[...] lo saturó de conservatismo y lo convenció que los liberales eran pecadores públicos"'4.

La estadía en Valdivia (y algunas otras regiones a orillas del río Cauca), el trabajo interino en Remedios, la falta de una cultura de fuerte arraigue católico en estos dos sitios, su coadjutoría con el padre Yepes y la lectura de Historia de una alma, libro autobiográfico escrito por Santa Teresita de Lisieux, parece, despertaron en Builes su celo misionero, su ardor por la conquista espiritual de estos pueblos. En 1921 se instaló en Remedios como cura en propiedad.

Según las propias palabras del obispo, Remedios fue una parroquia que sacó gotas de sudor de su frente, gotas de sangre de su corazón y lágrimas ardientes de sus ojos ${ }^{5}$. Zapata Restrepo dice en La Mitra Azul que Builes tuvo una disputa encarnizada en esta localidad con la familia Moreno, llegando incluso a sugerir que tal familia fue cómplice en un atentado contra la vida del sacerdote ${ }^{6}$.

De acuerdo con Francisco Ordoñez, en su libro Historia del cristianismo evangélico en Colombia, el misionero estadounidense Juan G. Touzeau, quien fundó la iglesia presbiteriana en Medellín y vivió en el departamento entre 1889 y 1907, visitó y formó un grupo de creyentes protestantes en Remedios que se reunían con regularidad 7 . Por su parte, El Adalid, semanario fundado en 1926 y dirigido en alguna época por Builes, publicaba en su número I 42 que los protestantes habían visitado en repetidas ocasiones Remedios sin ningún resultado concreto gracias a la solicitud del clérigo ${ }^{8}$. Lo cierto, es que muy temprano en el ministerio de Builes el asentamiento de protestantes en su diócesis empezó a ser parte de sus preocupaciones.

En la carta pastoral del 2 de febrero de 1925, siendo ya obispo, condenó rotundamente el matrimonio civil de dos parroquianos de Remedios, calificándolo de apostasía,

4 ZAPATA RESTREPO, Miguel. La mitra azul. Miguel Ángel Builes: El hombre, el obispo, el caudillo. Medellín: Editora Beta, 1973, págs. 36-37.

5 BUILES GÓMEZ, Miguel Ángel. La apostasía. En: BUILES GÓMEZ, Miguel Ángel. Cartas pastorales 1924- 1939. Medellín: Bedout, 1958, pág. 33.

6 ZAPATA RESTREPO. Op. Cit., pág. 39.

7 ORDOÑEZ, Francisco. Historia del cristianismo evangélico en Colombia. Medellín: Tipografía Unión, 1956, pág. 76.

8 OLANO GARCíA, María Dolly. Monseñor Builes, el hombre, el apóstol, el místico. Cali: Cuadernos de vida cristiana, 1979, pág. 77.

Revista Grafía Vol. 14 N I - enero-junio 2017 - p. 9-22 - ISSN 1692-6250 
Un hecho asaz doloroso ha venido a nublar la aurora de nuestro episcopado y a clavar una espina cruel en nuestro corazón de padre de almas: es el crimen de la APOSTASÍA que a los pocos días de nuestra consagración episcopal cometieron dos amados hijos nuestros, precisamente en la parroquia donde tantas gotas de sudor brotaron de nuestra frente, tantas gotas de sangre se arrancaron de nuestro corazón y tantas lágrimas ardientes encharcaron nuestros ojos [...] el deseo de casarse civilmente, realizando así de una manera oficial el gran escándalo de unirse en público concubinato $[\ldots]^{9}$.

Para monseñor Builes la apostasía era peor que la herejía, pues el hereje niega una o algunas verdades de la fe católica, el apóstata, las niega todas ${ }^{10}$. En ese sentido, el prelado encontró mayor pecado en el liberalismo que en el protestantismo.

Builes, ya como Obispo, emprendió el propósito misionero que tenía desde hacía varios años. Empezó a realizar viajes de misión por el norte de Antioquia en lo que correspondía a la Diócesis de Santa Rosa de Osos. El libro Crónicas Misionales, escrito por un anónimo bajo el seudónimo de "Un Padre Misionero", pero que al parecer era el mismo Builes" ", relata las visitas del prelado a diferentes poblados, veredas y caseríos del Occidente, el Norte y Nordeste antioqueño. El libro es un testimonio clave para analizar el celo apostólico de monseñor Builes.

Builes estuvo llevando su mensaje a un pueblo que desconocía muchas veces las cosas más sencillas de la religión. ¿Cuál sería la sorpresa del Obispo al saber que en su diócesis había personas tan ignorantes en la materia? En su visita a Caucasia y sus alrededores, el "Padre Misionero", informa de algunos acontecimientos que reflejan la sorpresa de los enviados de la Iglesia,

Muchos vecinos de Palotal, región limítrofe con Ayapel, vinieron también: pero como salieron del vientre de sus madres en cuanto a conocimientos religiosos. Figúrese Ud., Sr. Director, que examinando a uno de 55 años le preguntaba: ¿Ud. ha oído hablar de Dios? Me contestó: Mi Padrecito, primera vez que oigo hablar de esas cosas. Figúrese pues cómo estarán los niños y las niñas. Me pasó una muy buena, exactamente igual a la acaecida en otra ocasión al Sr. Obispo en sus giras misionales. Pregunté a una muchacha de unos 16 años algo sobre Dios, a ver si tenía idea de El: nada pudo contestarme. Le pregunté quién hizo el sol, la luna, la tierra, el río, los árboles... Nada! Me vino la tentación de preguntarle: A Ud. quién la hizo? Y vea la respuesta: "A yo? Pues mi mamál2.

9 BUILES GÓMEZ, Miguel Ángel. La apostasía, Op. Cit., pág. 33.

10 Ibíd., pág. 34.

I I OLANO GARCÍA, Op. Cit., pág. 37.

12 ANÓNIMO. Crónicas misionales o relatos de visitas pastorales practicadas por el Excmo. Sr. Dr. Dn. Miguel Ángel Builes dignísimo Obispo de Santa Rosa de Osos. Medellín: Librería y Tipografía Buffalo, 1934, pág. 64. 
Pero esta mentalidad virgen, sin teoría, estaba expuesta a múltiples formas de espiritualidad. En 1927 se encuentran en un mismo lugar, Peque (en el occidente lejano antioqueño), monseñor Builes y el exsacerdote y, luego, predicador evangélico Juan Esteban Roldán. Roldán, oriundo de Santa Rosa de Osos, conoció el mensaje protestante en Ituango donde entró en contacto con unos misioneros presbiterianos más o menos en el año 1918. Peque, también había sido uno de los primeros lugares donde los protestantes encontraron refugio en Antioquia. El libro Crónicas Misionales relata así el encontrón teológico-misionero entre Roldán y Builes.

[...] Desde la primera plática los predicadores católicos rompieron fuego contra el protestantismo y sus propagadores y secuaces. Habrá de saberse que el P. Juan Esteban vino expresamente a Peque a "contrarrestar la propaganda diabólica del Obispo Builes". Pobrecito! Como si éste no le hubiera infligido doscientas mil derrotas... Predicaron cuatro veces por día y no se les quedó doctrina católica rechazada por el protestantismo que no expusieran, ni error que no refutaran. El auto de visita fue un sumum de doctrina católica contra el protestantismo. [...] A poco de salir el Prelado (Miguel A. Builes) y los sacerdotes que le acompañaban salió él (Juan Esteban Roldán) para Dabeiba a vivir la vida de pureza que proclamó también en un sermón, declarando que ellos iban tras la huellas de los apóstoles, sin duda porque estos tenían negra en Dabeiba $[\ldots]^{13}$.

La expresión "[...] porque estos tenían negra en Dabeiba" identifica a Roldán y a los misioneros norteamericanos con los reformadores del siglo XVI, específicamente con Lutero quien al parecer de Builes y del catolicismo más radical colombiano se había robado una monja para vivir en concubinato con ella'14.

El obispo Builes parecía perturbado ante la idea de que fuera un sacerdote oriundo de Santa Rosa el predicador insigne de los protestantes en su diócesis. "Siendo todavía párroco de Remedios publicó algunas hojas dirigidas al Padre Juan Esteban Roldán, cuando éste había abandonado la fe católica"'15. En 1924, Builes, envió un sacerdote a Dabeiba para convencer a Roldán de su error; en 1927 el mismo Builes refutó sus ideas en Peque; años más tarde, encomendó la tarea de conversión al catolicismo del padre Roldán al padre Jesús María Urrea quien lo persuadió de establecerse en Medellín. La biógrafa de monseñor Builes, María Dolly Olano García, misionera teresita, afirmó en el libro Monseñor Builes, el hombre, el apóstol, el místico, que Roldán murió reconciliado con la Iglesia y auxiliado con todos los sacramentos ${ }^{16}$. Por su parte la hija del exsacerdote, Ninfa Roldán, en una entrevista concedida a Andrés Ríos Molina aseguró que,

\footnotetext{
13 Ibíd., págs. 13-14. Paréntesis añadido.

I4 GROOT, José Manuel. Los misioneros de la herejía o defensa de los dogmas católicos. Bogotá: Imprenta de Féliz Torres Amaya, 1853, pág. 96.

15 OLANO GARCíA. Op. Cit., pág. 382.

16 Ibíd., pág. 155.
} 
[...] él nunca negó lo que era hasta que expiró. Cuando ya se estaba muriendo llegó el cura a ponerle los santos óleos con una cantidad de godos y nos mandaron sacar a todos. Yo era chiquita y escondida miraba por entre una cortina. 'Padre Roldán, ¿es usted católico?' 'Si '. 'Apostólico' 'Sî. '¿Romano?' 'No, yo soy cristiano', decía entre dientes porque casi no podía hablar. Cuando fueron a santiguarlo él les quitaba con las manos y con los pies con la poca fuerza que tenía. Al momentico murió y salieron diciendo que había muerto con la fe católica el padre Roldán ${ }^{17}$.

\section{Predicar contra el protestantismo}

El ideario conservador de Builes nace desde su familia, desde las costumbres religiosas de éstos y de los lugares donde creció, se educó y empezó su ministerio: Donmatías, Santa Rosa, San Pedro, Toledo. La fortaleza mental de Builes muestra a un hombre comprometido con su causa desde muy joven, una persona que había tenido una profunda experiencia espiritual que le había formado y creado principios y metas de vida. Builes no tenía grandes negocios que defender y en buena parte de su vida no necesitó compromisos políticos con los liberales.

El discurso antiprotestante de monseñor Builes no salió de la nada, su propia experiencia de vida, el contexto histórico en el que creció, sus estudios religiosos, las lecturas que hizo, su teología escatológica, su mística y el ambiente geográfico en el que se movió, crearon en el obispo un vehemente deseo por mantener "puro" a un pueblo que amaba hasta las entrañas.

No es de extrañar el amor celoso del obispo por su Diócesis. Descontextualizar las palabras, escribir sin comprender, juzgar desde el presente, no puede ser un método de análisis serio, Builes habló, con amor, dolor y violencia. Su ataque oratorio fue principalmente contra el mismo Satanás, a quien veía en la Historia como aquel que estaba dispuesto a acabar con la Iglesia de Dios. Su discurso tenía la intención de mostrar al pueblo lo que éste no podía ver con claridad y de hacerle entender lo que él ya sabía. Aquello que Paul Ricœur llamó mimesis, "[ . . . ] una representación de la acción que produce lo nuevo, lo que no estaba allí o lo que no era visible, y se devela y se pone en público por mediación de las palabras con el propósito de cambiar el escenario y producir efectos pertinentes en el mundo de la experiencia"|18.

Ricœur habla de la trama discursiva como una mediación entre la experiencia y el oyente. La construcción de la trama es una actividad mediadora entre dos estadios. La idea con construir un discurso es la de cambiar el obrar del oyente o el lector ${ }^{19}$. Paul Ricœur divide la mimesis o construcción de la trama, en tres partes, la mimesis I o pre-figuración; la mimesis II o con-figuración y la mimesis

17 RÍOS MOLINA, Andrés. Identidad y religión en la colonización del Urabá antioqueño. Bogotá: Editorial Comunicón, 2002, pág. 30.

I8 URIBE DE HINCAPIÉ, María Teresa y LÓPEZ MARíN, Liliana María. Las palabras de la guerra. Medellín: La Carreta Editores, 2006, pág. II.

19 RICEUR, Paul. Tiempo y narración I: Configuración del tiempo en el relato histórico. México: Siglo XXI Editores, 2007, págs. ||4-||5. 
III o re-figuración. En la mimesis I, se busca comprender las estructuras de la acción en general, los símbolos de la acción y el tiempo de la acción (este tiempo sobrepasa los límites de la temporalidad del momento, o sea, será un tiempo complejo — pasado, mítico o imaginario_-). En la mimesis II, se anotan los acontecimientos particulares, los hechos, y se va construyendo una historia con sentido, que se pueda digerir por el lector o el oyente, se integran estos hechos como las partes de un todo y se muestran como consecuentes en el tiempo; en mimesis III, el tribuno interactúa con sus oyentes y el oyente mismo creará su propia realidad.

Para comprender el mensaje antiprotestante de Builes, es valioso mirar su vida, pero también sus escritos. En "El Protestantismo" y "El Juramento Católico" se revelan las ideas que el obispo tenía de los evangélicos y el rol de estos en el cumplimiento de las señales de los últimos tiempos. Los dos escritos brotan de coyunturas sociales que quebrantaron el alma del obispo: el establecimiento de una iglesia protestante en la jurisdicción de la Diócesis de Santa Rosa y el 9 de abril de 1948 respectivamente.

En la pastoral, El Protestantismo, Builes expresa que el propósito de esta era explicar el peligro que representan los protestantes para Colombia. Su motivación para escribirla se da gracias a una nueva iglesia evangélica en su Diócesis; el desarrollo de la misma tiene los tres componentes de prefiguración, configuración y refiguración de los que habla Ricœur. En la introducción de esta pastoral se puede notar esta estructura.

"Como introducción a nuestra exposición dogmática recordemos brevemente la historia de los fundadores del protestantismo para que deduzcamos qué frutos podrá producir tal árbol"20. En la historia según interpretación de Builes, los fundadores reformados son tratados como satánicos, orgullosos y lascivos. En segundo lugar, el análisis de Builes configura a los reformados desde el catolicismo, habla de las condenaciones de la secta, compara un buen número de las doctrinas protestantes con los dogmas de fe católicos, al tiempo que "desenmascara" los errores de los rebeldes y advierte que dichas ideas han moldeado el temperamento de los hombres perversos; finalmente el obispo concluye su pastoral alegando que el protestantismo es una quinta columna diabólica, "por fin, como el protestantismo en toda América Latina, y en nuestra patria colombiana principalmente, es una quintacolumna sumamente peligrosa para nuestra soberanía"2!.

Es de resaltar que la pastoral El protestantismo tiene una lógica estructural que lleva un norte, busca generar una convicción en el lector y en los oyentes. Los agentes de la desgracia (mimesis I) son los propios reformadores, los frutos de estos son la lascivia, la hipocresía y la herejía según el prelado. Builes se pregunta los qué y los porqués de la Reforma y le encuentra sentido en el marco de la profecía bíblica.

Siguiendo a Ricœur, en mimesis II, la trama de la pastoral transforma los hechos en historia, se unen las acciones individuales con los acontecimientos para formar un discurso teleológico. Así por

20 BUILES GÓMEZ, Miguel Ángel. El Protestantismo. En: BUILES GÓMEZ, Miguel Ángel. Cartas pastorales del excelentísimo señor Miguel Ángel Builes, Obispo de Santa Rosa de Osos, 1940-1948. Bogotá: Empresa Nacional de Publicaciones, 1957, pág. 303.

21 Ibíd., pág. 303. 
ejemplo monseñor Builes prueba con hechos históricos que el protestantismo es una quinta columna que busca arrebatar la unidad de la patria. De igual manera, la tercera parte de su diatriba en El Protestantismo el obispo buscó interactuar con oyentes y lectores (mimesis III),

"Léase esta Pastoral por partes, sin comentarios, hasta su terminación, en todas las misas que se celebren durante el primer mes de su recepción, o en un número mayor de domingos según el tiempo de que se disponga en cada parroquia. Terminada así la lectura, se seguirá después comentando cada punto y cada dogma, ojalá por escrito, durante todo el año, para que los fieles se empapen bien de los dogmas, amen su Religión, conozcan las falacias y argucias de los enemigos y los sepan refutar conociendo la doctrina católica. Este año será, pues, un año de predicación antiprotestante".22

Por su parte en el Juramento Católico, la alocución de Builes en la procesión del Sagrado Corazón de Jesús en junio de 1948, el Obispo de Santa Rosa, integró la historia del cristianismo y la historia de la iglesia a la historia universal para darle un sentido a los acontecimientos ocurridos en Colombia. Desde el Sanedrín donde se preparaba la muerte del Justo, pasando por Nerón, las herejías y la Reforma, Builes llevó su discurso hasta la masonería y el comunismo, todas las sectas anticristianas, cuyo único fin era destruir el reinado de Cristo ${ }^{23}$.

\section{Apocalipsis en Colombia}

Para el obispo Builes los sucesos del nueve de abril no eran otra cosa que la confirmación de las profecías apocalípticas del apóstol Juan, el sovietismo ruso era la bestia de siete cabezas, diez cuernos y diez diademas de Apocalipsis 13 que se empecinaba en destruir a la Iglesia de Dios ${ }^{24}$.

De seguro algunas partes del texto sagrado no cuadraban en la imagen histórica que tenía monseñor Builes, pero otras eran más que claras, el dragón eran Satanás; la bestia, era el comunismo, lleno de poder y al que se estaban doblegando las naciones, hablando contra Dios, contra la Iglesia y haciendo la guerra a los santos; como el leopardo, también, lleno de colores en sus variadas costumbres; como el oso, porque todo lo atropella y pisotea, aún lo más sagrado: la Eucaristía; y como el león, por la ferocidad y saña para despedazar a sus adversarios. Las demás partes del texto apocalíptico se integrarían a la historia del mundo que, al parecer del Obispo, llegaba a su fin.

En la biblioteca que monseñor Builes tenía en su casa en Santa Rosa de Osos, en la que vivió entre 1924 y 1958, se destacan títulos de marcada orientación místico-apocalíptica y antiprotestante:

22 Ibíd., pág. 38I.

23 BUILES GÓMEZ, Miguel Ángel. El juramento católico. En: BUILES GÓMEZ, Miguel Ángel. Cartas pastorales del excelentísimo señor Miguel Ángel Builes, Obispo de Santa Rosa de Osos, 1940-1948. Bogotá: Empresa Nacional de Publicaciones, I957, págs. 400-402.

24 Ibid., pág. 404. 
Variaciones de las iglesias protestantes de Santiago B. Bousset, una colección de las obras de Hugo Wast ${ }^{25}$ y los cuatro tomos de Visiones y revelaciones completas de Ana Catalina Emmerick, entre otros. La visionaria alemana decía por ejemplo, "Vi también en Alemania a eclesiásticos mundanos y protestantes iluminados manifestar deseos y formar un plan para la fusión de las confesiones religiosas y para la supresión de la autoridad papal [...] ellos construían una iglesia, extraña y extravagante; todo el mundo tenía que entrar en ella para unirse y poseer allí los mismos derechos; evangélicos, católicos, sectas de todo tipo [....'26.

Builes miraba la historia desde el presente hacia el pasado, desde el comunismo hasta el cristianismo, desde Gaitán hasta Cristo. En una parte de esa historia lineal y retrospectiva se ubicaba el protestantismo que empezaba a inmiscuirse de manera peligrosa en la Diócesis de Santa Rosa de Osos, confabulado, queriéndolo o no, con el liberalismo norteamericano y el comunismo soviético, que para Builes no eran contradictorios, sino la simple línea de la corrupción diabólica. Desde esa óptica, monseñor Builes miraba al protestantismo como una quintacolumna imperialista que buscaba destruir la unidad de la patria,

En esta pastoral queremos alertar a nuestros amados hijos contra esta invasión, mucho más peligrosa que las quintacolumnas de Hitler y Stalin, porque aquellas han ido de una vez a la conquista material, mientras que la quintacolumna protestante ataca la Fe para arrebatarnos después la Patria [...] La infiltración quintacolumnista es el método empleado para llegar tarde o temprano al ideal de Panamericanismo que nosotros entendemos así: América para los americanos, América Latina para la América del Norte ${ }^{27}$.

Al decir, monseñor Builes, que el protestantismo era una quintacolumna de un poder mayor identifica a los protestantes como aparatos de una guerra. Un sector minoritario de la población que colabora con los enemigos. Parece atrevido, pero necesario, argumentar que el obispo de Santa Rosa sentía que una invasión protestante, y a la vez del sistema capitalista (liberal) norteamericano a Colombia, iría destruyendo las costumbres conservadoras en el país, lo que finalmente llevaría al culmen de la apostasía: el comunismo soviético que se levantaría contra todo lo que se llame Dios y sea objeto de culto: "Para eso sirven las quintacolumnas y los quintacolumnistas protestantes. Consignémoslo sin vacilaciones: la propaganda protestante es una amenaza para la nacionalidad. En estos precisos momentos el gobierno y la Patria están sufriendo los ataques más alevosos del quintacolumnismo

25 Hugo Wast (1883-1962) era el seudónimo de Gustavo Adolfo Martínez Zuviría. Fue un escritor polémico debido a su antisemitismo y a su simpatía por el franquismo. Defensor a ultranza de la Iglesia católica. Es evidente en su estilo cierto tipo de mesianismo católico propio del siglo XIX. Por ejemplo, Juana Tabor, una de sus obras, es la historia de un fraile que gracias a su racionalismo, deseos ecuménicos y admiración erótica hacia una mujer terminará cayendo en una herejía tal como para darle entrada en la historia mundial al anticristo.

26 CLEMES BRENTANO et al. Visiones y revelaciones de la Ven. Ana Catalina Emmerick. Tomo XV. Profecías del fin del mundo. Editorial Surgitei, pág. 15. [citado 7, febrero, 20I I]. Disponible en: http://es.scribd.com/doc/31828582/Visiones-y-Revelacionesde-Ana-Catalina-Emmerick-Tomo-XV.

27 BUILES GÓMEZ, Miguel Ángel. El Protestantismo, Op. Cit., págs. 3 I 0-3। I. 
soviético instalado en la embajada rusa; mañana, y más breve de lo que pueda pensarse, sentirán en carne viva los puñales que está afilando la quintacolumna protestante"'28.

Con el aliciente de que la mayoría de las misiones protestantes en Colombia y en Antioquia se instalaron en regiones predominantemente liberales ${ }^{29}$, la visión escatológica de monseñor Builes cuadraba armónicamente con las profecías bíblicas y con el llamado del integrismo católico a instalar el reino de Dios en la tierra. Según Jean Baubérot, el integrismo católico tiene su génesis en un sector del clero que inspirado en la encíclica Rerum Novarum decidió entrar al mundo moderno para transformarlo desde dentro. El integrismo está inspirado en la defensa que hizo la Iglesia frente a la Reforma protestante, la Revolución francesa y la Modernidad ${ }^{30}$.

La llegada al poder del liberalismo en 1930 es para el prelado el comienzo de una violencia fratricida por parte de los liberales contra los conservadores, "De la horrenda crueldad de los sicarios del liberalismo ha sido testigo toda Colombia; pero de manera especial los Santanderes de 1930 en adelante [...]"3!. Enrique Olaya Herrera encarna todos los temores del obispo, "Olaya Herrera, que llegó entre un coro de aduladores proclamado como salvador del país; comprometido con los protestantes norteamericanos y amistado con la masonería; tolerante con socialistas y comunistas $[\ldots]^{\prime \prime 32}$.

Para 1948, según el obispo el año de predicación antiprotestante, Builes nuevamente relaciona a los evangélicos con el liberalismo norteamericano y con el comunismo ruso, "Al estilo de Rusia, que fomenta el hambre y la miseria material para atrapar naciones, los protestantes norteamericanos fomentan el hambre y la miseria espiritual, descatolizando los pueblos en que tienen puestos sus ojos plenos de ambición conquistadora" ${ }^{\prime 3}$. Por eso es adecuado encontrar la forma en que Builes configuró su discurso contra los protestantes más que en hechos políticos puntuales en su propia teología escatológica. No que su conocimiento del liberalismo, comunismo o protestantismo no aportara al desarrollo de su pensamiento, sino que el eje sobre el que se movían sus ideas era la teología.

Así, los problemas por los que estaba atravesando la Iglesia en Colombia para mitad del siglo XX, son los mismos por los que había pasado la Iglesia universal un siglo atrás. La muerte del líder liberal

28 Ibíd., págs. 318-319.

29 En Antioquia para 1946 existían misiones protestantes en Amalfí, Anorí, Antioquia (Santa Fe de Antioquia), Bello, Caucasia, Dabeiba, Giraldo, La Unión, Medellín, Peque, Puerto Berrío, Remedios, Rionegro, Santa Bárbara, Segovia, Turbo y Zaragoza. La mayoría, municipios liberales. Ver: CARBALLO, Fabio Hernán. La persecución a los protestantes en Antioquia durante la violencia bipartidista de mediados del siglo XX. Medellín: IDEA, 2010.

30 TINCQ, Henri. La Escalada de los extremismos religiosos en el mundo. En: DELUMEAU, Jean (Dir.). Traductor Eliane CazenaveTapie. El hecho religioso, una enciclopedia de las religiones hoy. México: Siglo XXI, 1997, pág. 517.

3I BUILES GÓMEZ, Miguel Ángel. Nuestros Mártires Sacerdotes. En: BUILES GÓMEZ, Miguel Ángel. Cartas pastorales del excelentísimo señor Miguel Ángel Builes, obispo de Santa Rosa de Osos, 1949- 1957. Bogotá: Empresa Nacional de Publicaciones, 1957, pág. 178.

32 ZAPATA RESTREPO. Op. Cit., pág. 149.

33 BUILES GÓMEZ, Miguel Ángel. El Protestantismo, Op. Cit., pág. 3 |4. 
Jorge Eliecer Gaitán no podía ser vista de otra manera, sino como el complot, más que comunista, diabólico contra la obra de Dios ${ }^{34}$. "Colombia, hermanos míos, es un remedo del mundo, y en ella hay de todos esos contradictores de Cristo que le dominan y que siembran el odio a todo lo sagrado, a todo lo santo. Sobre su suelo, preparado por esos contradictores de Cristo, el oso apocalíptico [... ] asentó el 9 de abril de este año de 1948 su planta maldita, y para ello se alió con hijos innobles de esta Patria desgraciada, los que ya conocéis"35.

Monseñor Builes, prefiguró y configuró su discurso antiprotestante. El Obispo ubicó a los protestantes de Antioquia como parte del complot diabólico contra la religión y la patria, lo que Paul Ricœur llama mimesis l, la parte inicial del entramado discursivo, donde se busca comprender las estructuras de la acción en general, los símbolos de la acción y el tiempo de la acción. El protestantismo colombiano, según Builes, era parte de una estructura mundial satánica de guerra contra la Iglesia, nació en el siglo XVI y había vivido, desde ese entonces, en la constante inmoralidad. Builes se encargó de crear, o por lo menos de fomentar, el imaginario de los antioqueños sobre los protestantes percibiéndolos como personas perversas, sin moral, que se reunían en secreto para realizar, seguramente, actos lascivos al igual que sus fundadores,

El protestantismo con su doctrina de que basta creer para salvarse sin necesidad de obras buenas, echa por tierra los mandamientos de Dios para que sean pisoteados sin peligro de perderse, dicen ellos, con lo que intentan justificar la abominación de una vida de pecado [... Cuando ya no quieren guardar (los sacerdotes disidentes) el voto de castidad se adentran por la senda que trazaron los fundadores del protestantismo Lutero, Zuinglio y Calvino, quienes colgaron sus vestiduras sacerdotales para entregarse sacrílegamente a los vicios de la carne ${ }^{36}$.

Pero Miguel Ángel Builes también integró a su discurso escatológico antiliberal, los acontecimientos particulares que se relacionaban con los protestantes, una nueva misión evangélica en uno de los pueblos de su diócesis se convertía en una guerra religiosa, "la desgracia inenarrable de haber establecido los protestantes un segundo centro de herejía en nuestra amada Diócesis en estos últimos días, y el peligro que este hecho entraña nos obliga a escribir nuestra Carta Pastoral de este año sobre el peligro protestante, peligro que amenaza no sólo la integridad de la fe sino la misma nacionalidad colombiana $[\ldots]^{\prime 3}$.

El oso apocalíptico había pisado por medio de los contradictores de la Iglesia, lo más sagrado, la Eucaristía, los protestantes decían que el Cuerpo de Cristo era una oblea; los hijos innobles de la

34 Puede leerse también la pastoral El verdadero autor de la hecatombe del 9 de abril, En: BUILES GÓMEZ, Miguel Ángel. Cartas pastorales del excelentísimo señor Miguel Ángel Builes, Obispo de Santa Rosa de Osos, 1940-1948. Bogotá: Empresa Nacional de Publicaciones, 1957. págs. 385-388.

35 BUILES GÓMEZ, Miguel Ángel. El juramento católico, Op. Cit., pág. 406.

36 BUILES GÓMEZ, Miguel Ángel. El Protestantismo. Op. cit., pág. 378. Paréntesis añadido.

37 Ibíd., pág. 303. 
patria habían destruido imágenes sagradas, los protestantes en sus folletos se mostraban iconoclastas; en los sucesos del nueve de abril del cuarenta y ocho turbas enfurecidas dañaron altares y templos ¿quiénes hablaban contra estos santos lugares, sino los protestantes? Eran parte íntegra del complot diabólico contra la Iglesia.

\section{Algunas conclusiones}

El discurso de Builes contra los evangélicos pasó de la pre-figuración y con-figuración a la re-figuración. Sus pastorales, leídas en las iglesias, forjaron sentimientos en las personas que las escuchaban. Y al educar la irracionalidad del pueblo las gentes actuaron de manera violenta contra los protestantes.

Dos conclusiones generales y algunas particulares. Para empezar, y comenzando en retrospectiva, una conclusión teológica: el discurso antiprotestante de monseñor Builes no tenía como foco primordial a los protestantes mismos. Aunque Builes escribió una pastoral llamada "El Protestantismo" donde atacaba las ideas protestantes y daba instrucciones para su detener tal "virus" en su diócesis, la retórica general del obispo los enmarcaba dentro de la lucha escatológica de Satanás contra la Iglesia de Dios. Esto es representativo en el intento de entender al prelado, para comprender a Builes hay que comprender su teología y muy especialmente su escatología.

En segundo lugar, una conclusión más ontológica: Años de desasosiego espiritual fueron los de la República Liberal para el prelado ¿Qué llegaría a la mente del obispo al enterarse de los triunfos del liberalismo y el comunismo internacional? Builes sentía el olor a apostasía en su mismas narices ¡Qué diferente el celebrar una misa en Donmatías a una a las orillas del Cauca! El contraste entre Remedios y Santa Rosa, entre Valdivia y Toledo, entre Peque y Donmatías (por poner cualquier orden) hizo su trabajo en el alma del joven misionero. Corpúsculos de protestantes siempre estuvieron presentes en las andanzas de Miguel Ángel Builes. Nació en 1888, en 1889 llegó el primer misionero presbiteriano a Medellín. Allende a esto, su onomástico marcó su devenir. Y una hierofanía, el 29 de septiembre día de San Miguel en 1942, luchando contra las reformas concordatarias, el arcángel Miguel le dio su espada,

Eran las 5 de la mañana de ese día feliz: yo me postré en mi reclinatorio casi al pie de la imagen de San Miguel, de tamaño de un hombre normal y después de saludar a Nuestro Amo, dirigí mi saludo fervoroso a San Miguel y le recé un Padrenuestro [...] mi ardiente súplica conmovió a San Miguel, quien soltó de la diestra la espada, la cual se vino rodando sobre las gradas de los cirios y con buen ruido cayó de punta sobre el altar en el lugar preciso donde se colocaría el misal [...] Me acerqué al altar, tomé con mi diestra la punta afilada y la troqué por el mango, me acerqué al sagrario y toqué delicadamente la puerta con la punta de la espada; alcé ésta ante mi Santo Arcángel y le di las gracias porque así me armaba ante el Señor y pasé luego al lado del Evangelio donde estaba la estatua de Santa Teresita y le rendí mi 
espada jurándole que defendería con ella los derechos de mi Dios ultrajado por mis enemigos ${ }^{38}$.

La misión para Builes era muy clara: defender la religión. El enemigo era uno solo: Satanás. Protestantismo, liberalismo, racionalismo, socialismo, comunismo, eran hijos del un mismo padre. Y dicho padre, según el texto de Apocalipsis 12:7 sería derrotado por Miguel y sus ángeles ${ }^{39}$.

\section{Fuentes}

ANÓNIMO. Crónicas misionales o relatos de visitas pastorales practicadas por el Excmo. Sr. Dr. Dn. Miguel Ángel Builes dignísimo Obispo de Santa Rosa de Osos. Medellín: Librería y Tipografía Buffalo, 1934.

BUILES GÓMEZ, Miguel Ángel. Cartas pastorales 1924-1939. Medellín: Bedout, 1958.

Cartas pastorales del excelentísimo señor Miguel Ángel Builes, Obispo de Santa Rosa de Osos, 1940-1948. Bogotá: Empresa Nacional de Publicaciones, 1957.

Cartas pastorales del excelentísimo señor Miguel Ángel Builes, obispo de Santa Rosa de Osos,

1949-1957. Bogotá: Empresa Nacional de Publicaciones, 1957.

GROOT, José Manuel. Los misioneros de la herejía o defensa de los dogmas católicos. Bogotá: Imprenta de Féliz Torres Amaya, 1853.

\section{Bibliografía}

\section{Libros, revistas e inéditos}

CARBALLO, Fabio Hernán. La persecución a los protestantes en Antioquia durante la violencia bipartidista de mediados del siglo XX. Medellín: IDEA, 2010.

CLEMES BRENTANO et al. Visiones y revelaciones de la Ven. Ana Catalina Emmerick. Tomo XV. Profecías del fin del mundo. Editorial Surgitei, pág. 15. [Citado 7, febrero, 20I I]. Disponible en: http://es.scribd.com/ doc/31828582/Visiones-y-Revelaciones-de-Ana-Catalina-Emmerick-Tomo-XV.

DELUMEAU, Jean (Dir.). El hecho religioso, una enciclopedia de las religiones hoy. México: Siglo XXI, 1997.

OLANO GARCíA, María Dolly. Monseñor Builes, el hombre, el apóstol, el místico. Cali: Cuadernos de vida cristiana, 1979.

ORDOÑEZ, Francisco. Historia del cristianismo evangélico en Colombia. Medellín: Tipografía Unión, 1956.

38 OLANO GARCÍA. Op. Cit., págs. 442-443.

39 "Pero éstos fueron los más débiles, y después no quedó ya para ellos lugar alguno en el cielo". La Sagrada Biblia. Por Don Félix Torres Amat. Madrid: Imprenta de León Amarita, 1824. 
RICCEUR, Paul. Tiempo y narración I. Configuración del tiempo en el relato histórico. México: Siglo XXI Editores, 2007.

RÍOS MOLINA, Andrés. Identidad y religión en la colonización del Urabá antioqueño. Bogotá: Editorial Comunicón, 2002.

SANÍN ECHEVERRI, Jaime. El Obispo Builes. Medellín: Editorial Géminis, 1988.

URIBE DE HINCAPIÉ, María Teresa, La territorialidad de los conflictos y la violencia en Antioquia. Medellín: Universidad de Antioquia, Instituto de Estudios Regionales (INER), 1990.

URIBE DE HINCAPIÉ, María Teresa y LÓPEZ MARÍN, Liliana María. Las palabras de la guerra. Medellín: La Carreta Editores, 2006.

ZAPATA RESTREPO, Miguel. La mitra azul. Miguel Ángel Builes: El hombre, el obispo, el caudillo. Medellín, Editora Beta, 1973. 